\title{
POSTER SEBAGAI MEDIA EDUKASI KONSERVASI CAPUNG DAN KUPU-KUPU BAGI PENGUNJUNG KAWASAN WISATA IRENGGOLO KEDIRI
}

\author{
Tutut Indah Sulistiyowati, Ida Rahmawati, Budhi Utami, dan Dwi Ari Budiretnani \\ Universitas Nusantara PGRI Kediri \\ tututindah@unpkdr.ac.id
}

\begin{abstract}
Abstrak
Telah dilakukan penelitian tentang poster sebagai media edukasi konservasi bagi pengunjun gkawasan wisara Irenggolo Kediri. Penelitian ini dilakukan sebagai evaluasi media edukasi konservasi bagi pengunjung. Teknik pengambilan data adalah dengan melakukan pengamatan terhadap poster yang dipasang di beberapa tempat strategis yang dikunjungi atau dilalui. Penelitian yang dilakukan pada bulan Juni hingga Desember 2018 ini adalah penelitian kualitatif. Hasil pengamatan disajikan secara narasi dan dalam diagram. Pengunjung anakanak akan kembali melihat poster sebanyak dua sampai empat kali. Pengunjung dewasa berhenti dan langsung membaca hingga akhir. Sebanyak 52\% pengunjung usia anak-anak menghabiskan waktu lebih dari lima menit untuk menyentuh poster dan langsung mencari kupu-kupu seperti pada gambar. Berdasarkan wawancara sederhana, sebanyak $83 \%$ pengunjung memberikan tanggapan positif terhadap informasi dalam poster.
\end{abstract}

Kata kunci: konservasi, kupu-kupu, poster

\section{PENDAHULUAN}

Kawasan wisata Irenggolo Kediri merupakan tujuan untuk rekreasi dan belajar bagi kurang lebih 52.487 orang pertahun. Kawasan ini berada pada ketinggian $1200 \mathrm{~m}$ dpl. Dengan ketinggian tersebut, kawasan ini memiliki suhu rata-rata yang optimal sebagai habitat berbagai hewan dan tumbuhan. Penelitian terdahulu menyebutkan bahwa keanekaragaman tumbuhan dan hewan di tempat ini cukup tinggi. Sulistiyowati dan Rahmawati, 2018 menyatakan bahwa sebanyak 246 individu capung dan 1.622 individu kupu-kupu telah teridentifikasi [1]. Jumlah ini tergolong tinggi apabila dibandingkan dengan luas wilayah dan banyaknya gangguan pengunjung. Keragaman kupu-kupu yang terdapat di kawasan wisata ini ditentukan oleh berbagai faktor, diantaranya adalah kondisi lingkungan yang kondusif sebagai habitat kupu-kupu, serta terdapatnya sumber daya yang memadai [2]. Berdasarkan study terdahulu diketahui bahwa kawasan wisata ini memiliki beragam tumbuhan yang merupakan habitat dan sekaligus pakan kupu-kupu [3][4]. Tumbuhan yang terdapat di kawasan ini selain tumbuh liar, ada juga beberapa yang sengaja ditanam untuk memperindah tempat. Masyarakat sekitar kawasan wisata Irenggolo kebanyakan menanam aneka bunga di sepanjang jalan menuju tempat wisata. Keberadaan kawasan wisata Irenggolo Kediri dapat meningkatkan penghasilan warga sekitar. Sebagian besar warga berprofesi sebagai pedagang dan buruh kebun. Latar belakang pendidikan warga paling banyak adalah tingkat SMA. Wawasan masyarakat tentang keragaman serangga masih rendah [5] sehingga perlu dilakukan edukasi tentang keragaman kupu dan upaya konservasinya.

Banyaknya jenis media edukasi yang tersedia, dapat memudahkan peneliti dan praktisi untuk melakukan komunikasi kepada audien. Pemilihan media yang tepat berpengaruh terhadap hasil yang baik. Berdasarkan penelitian terdahulu yang dilakukan oleh Prameswari, dkk (2017) diketahui bahwa poster merupakan media yang paling tepat sebagai sarana edukasi pengunjung kawasan wisata Irenggolo Kediri [6]. Poster didominasi dengan banyak gambar dan warna, sehingga menarik perhatian pengunjung yang paling banyak dari kalangan pelajar. Minat baca kaum muda dewasa ini tidak terlalu tinggi. Mereka lebih menyukai menggunakan ponsel pintar untuk mengakses informasi. Namun kebanyakan yang dilakukan adalah menggunakan ponsel untuk kepentingan lain, selain kepentingan edukasi.

Kawasan wisata Irenggolo Kediri telah dikelola dengan baik untuk kepentingan wisata dan rekreasi. Penambahan informasi tentang keragaman tumbuhan dan hewan yang ada di kawasan ini masih sangat minim. Pengunjung yang bermaksud mengunjungi kawasan ini untuk kepentingan belajar mengalami kesulitan mendapatkan informasi. Oleh sebab itu penting dilakukannya penelitian tentang poster sebagai sarana edukasi dan konservasi.

\section{METODE}

Penelitian ini dilakukan pada bulan Juni hingga Desember 2018 di kawasan wisata Irenggolo Kediri. Lokasi penelitian berjarak $\pm 24 \mathrm{~km}$ dari Universitas Nusantara PGRI Kediri (Gambar 1). Sebanyak enam poster 
dipasang pada enam titik yang paling banyak dikunjungi pengunjung. Poster yang dipasang sudah melalui tahap uji validasi dari ahli media dan isi, sehingga layak untuk diaplikasikan.

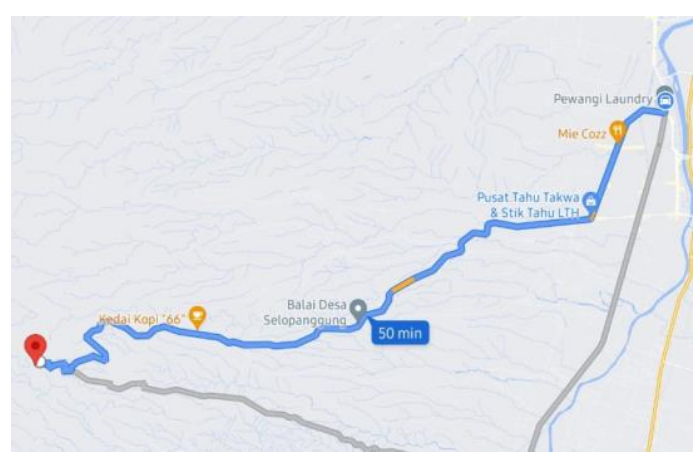

Gambar 1. Jarak lokasi penelitian dengan kampus Universitas Nusantara PGRI Kediri

Data pengamatan merupakan hasil observasi terhadap pengunjung yang menghampiri poster. Pengunjung dikelompokkan berdasarkan rentang usia anak-anak, remaja, dan dewasa. Pengamatan perilaku pengunjung dilakukan pada tujuh hari Sabtu dan Minggu, serta tujuh hari kerja, pada jam kunjungan. Data pengamatan merupakan data tabel waktu dengan selang waktu dua jam pada masing-masing pengamatan. Data yang diamati adalah berupa seberapa lama pengunjung berhenti untuk membaca poster, kemudian dikelompokkan ke dalam tabel berikut:

Tabel 1. Tabel pengamatan lama pengunjung membaca poster Jumlah pengunjung berdasarkan kategori usia

Lama membaca poster
$<3$ menit
$3-5$ menit
$>5$ menit

Berdasarkan data yang diperoleh, hasil pengamatan disajikan dalam diagram untuk memudahkan analisis.

\section{HASIL DAN PEMBAHASAN}

Berdasarkan hasil pengamatan diperoleh jumlah total pengunjung yang teramati adalah sebanyak 763 orang, yang terdiri atas 183 anak-anak, 296 remaja, dan 284 orang dewasa (Gambar 1). Kategori usia remaja paling banyak mengunjungi kawasan wisata ini untuk tujuan rekreasi. Remaja yang berkunjung adalah siswa tingkat SLTP dan SLTA di kawasan Kediri, Nganjuk, dan Jombang. Berdasarkan hasil pengamatan, remaja tidak tertarik untuk membaca pesan dalam poster (Tabel 1). Pengunjung remaja hanya melewati poster dan menikmati gambar, tanpa membaca. Berdasarkan penelitian sebelumnya, diketahui bahwa remaja dewasa ini tidak terlalu tertarik untuk membaca [7]. Alasan terbesar remaja membaca pengetahuan akademik adalah agar memiliki nilai akademik yang bagus, kompetisi, dan pengakuan sosial [8]. Sehingga apabila di luar alasan-alasan tersebut, kebanyakan remaja menghindari bacaan yang informatif. Remaja lebih menyukai bacaan nonakademis untuk alasan mengatasi rasa bosan, alasan-alasan sosial, dan mengikuti tren [9].

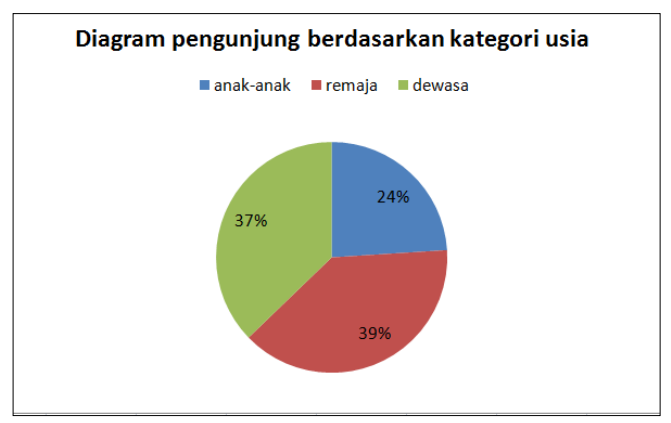

Gambar 1. Sebaran pengunjung berdasarkan kategori usia

Anak-anak memiliki ketertarikan khusus terhadap gambar dan warna [10]. Poster edukasi keragaman kupu-kupu ini didesain dengan warna dan gambar yang menarik sesuai dengan saran dari ahli. Berdasarkan waktu kunjungan, anak-anak adalah pengunjung yang paling banyak membaca dan mengamati poster (Gambar 2). Dengan atau tanpa bimbingan orang tua, anak-anak tertarik mengamati gambar dan beberapa diantaranya 
mencoba menyesuaikan kupu-kupu yang kebetulan dilihat dengan gambar, lalu meminta orang tuanya membacakan tulisan yang ada di bawahnya (Gambar 3).

Anak-anak memiliki tahapan perkembangan kemampuan membaca yang bertingkat dari hanya melihat warna, gambar, dan huruf [11]. Kehadiran orang tua dan guru sangat mempengaruhi kemampuan anak memahami informasi yang disampaikan secara tidak langsung. Berdasarkan hasil pengamatan, anak-anak yang mendengarkan orang tua membacakan tulisan dan menjelaskan isinya, mencari langsung kupu-kupu di sekitar.

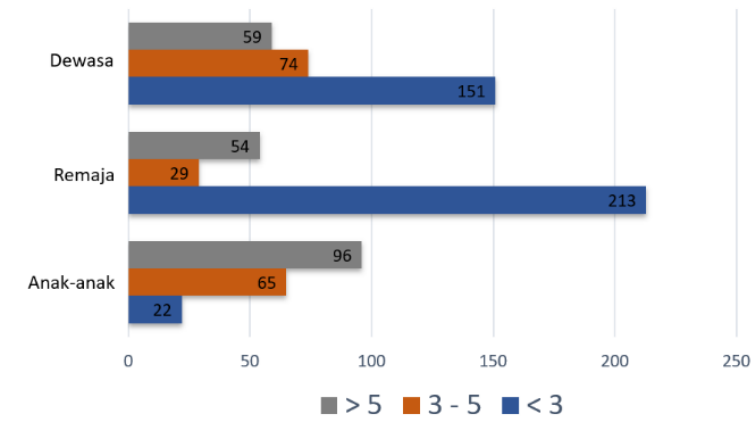

Gambar 2. Sebaran lama pengunjung membaca poster

Berdasarkan lama waktu yang dihabiskan untuk membaca poster, remaja memiliki jumlah terbanyak dalam kategori waktu membaca tersingkat. Gambar 2 menunjukkan hasil bahwa sebanyak 213 remaja menghabiskan waktu paling singkat di depan poster (kurang dari 3 menit). Kebanyakan mereka hanya melihat sekilas poster yang disajikan. Kategori pengunjung dewasa yang mengamati poster lebih dari lima menit hanya 59 orang. Orang dewasa jarang melihat poster karena terburu-buru menuju tempat yang diinginkan. Kebanyakan pengunjung dewasa yang berhenti lama di depan poster adalah karena anak-anak yang meminta untuk dibimbing. Dari keseluruhan pengunjung yang mengamati poster lebih dari lima menit telah diwawancarai pendapat mereka tentang poster yang diamati. Sebanyak $83 \%$ pengunjung memberi respon positif dengan adanya poster edukasi di tempat-tempat wisata seperti Kawasan wisata air terjun Irenggolo Kediri.
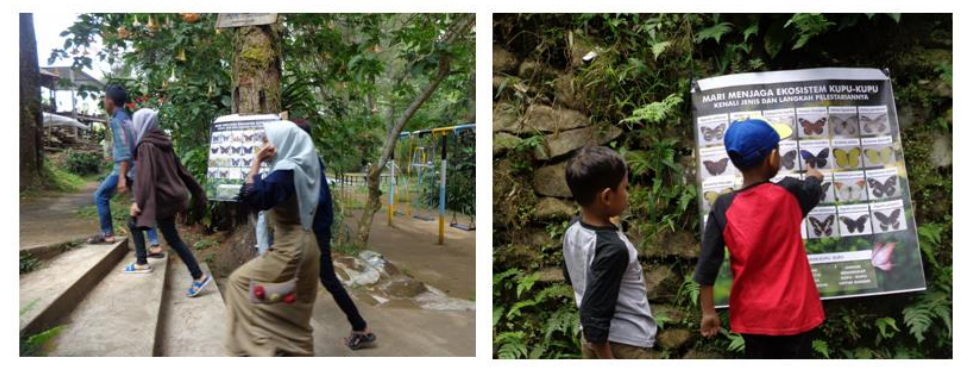

Gambar 3. Kelompok remaja yang mengabaikan poster dan kelompok anak-anak yang memperhatikan poster

\section{DAFTAR PUSTAKA}

[1] Sulistiyowati, TI dan Rahmawati, Ida. 2018. Keanekaragaman dan Kemelimpahan Kupu-Kupu di Kawasan Wisata Air Terjun Irenggolo Kediri. Stigma. Vol 11 No 2 (1-8)

[2] Fermon, H. 2002. The Butterfly Community of a Managed West African Rainforest: Patterns of Habitat Specificity, Diversity, Stratification and Movement. Dissertation. University of Gottingen, Gottingen, Germany.

[3] Rahmawati, Ida., Sulistiyowati, TI., dan Nurohim, Amila. 2018. Bagian Tumbuhan Yang Digunakan Capung (Odonata) Untuk Hinggap Di Kawasan Wisata Air Teriunirenggolo Kediri. Jurnal Biologi dan Pembelajarannya. Vol 5 No 2 (38-40)

[4] Rahmawati, Ida ., dan Sulistiyowati, TI. 2019. Jenis Tumbuhan yang Sering Dikunjungi Kupu-Kupu di Kawasan Wisata Air Terjun Irenggolo Kabupaten Kediri. Prosiding Seminar Hayati VII 2019 (1-5) 
JurnalBiologi dan Pembelajarannya, Vol 8 No 1, April 2021. Pp: 40-43

e-ISSN: $2406-8659$

[5] Sulistiyowati, TI. 2017. Tingkat Pemahaman Masyarakat Desa Besuki Terhadap Edible Insect : Kajian Awal Introduksi Berbagai Produk Olahan Berbahan Dasar Serangga Sebagai Sumber Protein. Prosiding Seminar Nasional PEI Cabang Bandung (189-191)

[6] Prameswari, IT., Sulistiyowati, TI., Sulistiono., Primandiri, PR. 2017. Media Pengenalan Jenis Capung (Odonata) Sebagai Langkah Awal Konservasi Capung di Kawasan Wisata Air Terjun Ironggolo Kabupaten Kediri. Prosiding Seminar Nasional PEI Cabang Bandung (64-66)

[7] Hidi, S. 2001. Interest, Reading, and Learning: Theoritical and Practical Consideration. Educational Psychology Review 13 (3).

[8] Schiefele, U., \& Schaffner, E. (2016). Factorial and construct validity of a new instrument for the assessment of reading motivation. Reading Research Quarterly, 51(2), 221-237.

[9] Gregory, R. J. (2004). Psychological Testing: History, Principles, and Applications, 4 th Ed. Boston, MA: Allyn and Bacon.

[10] Brewer, Jo Ann. 2007. Introduction Early Childhood Education Preschool Through Primary Grades, Sixth Edition. Boston: Allynan Bacon.

[11] Herlina, Emi Silvia. 2019. Membaca untuk Anak Usia Dini dalam Era Pendidikan 4.0. Jurnal Pioner LPPM Universitas Asahan 5(4): 332-342. 